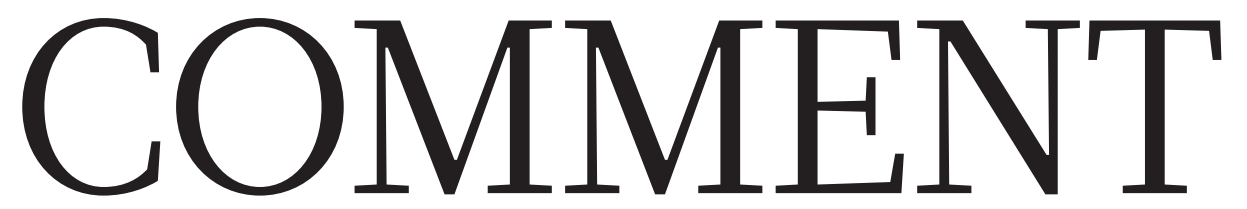

SUSTAINABILITY Manage rivers in a changing climate with process models $\mathbf{p . 3 0 1}$
GEOSCIENCE A paean to carbon-14 and the people who track its traces p.304
EQUITY Racism report academics at University of Cape Town reply p.307 obituary Murray Gell-Mann, particle predictor, remembered p.308

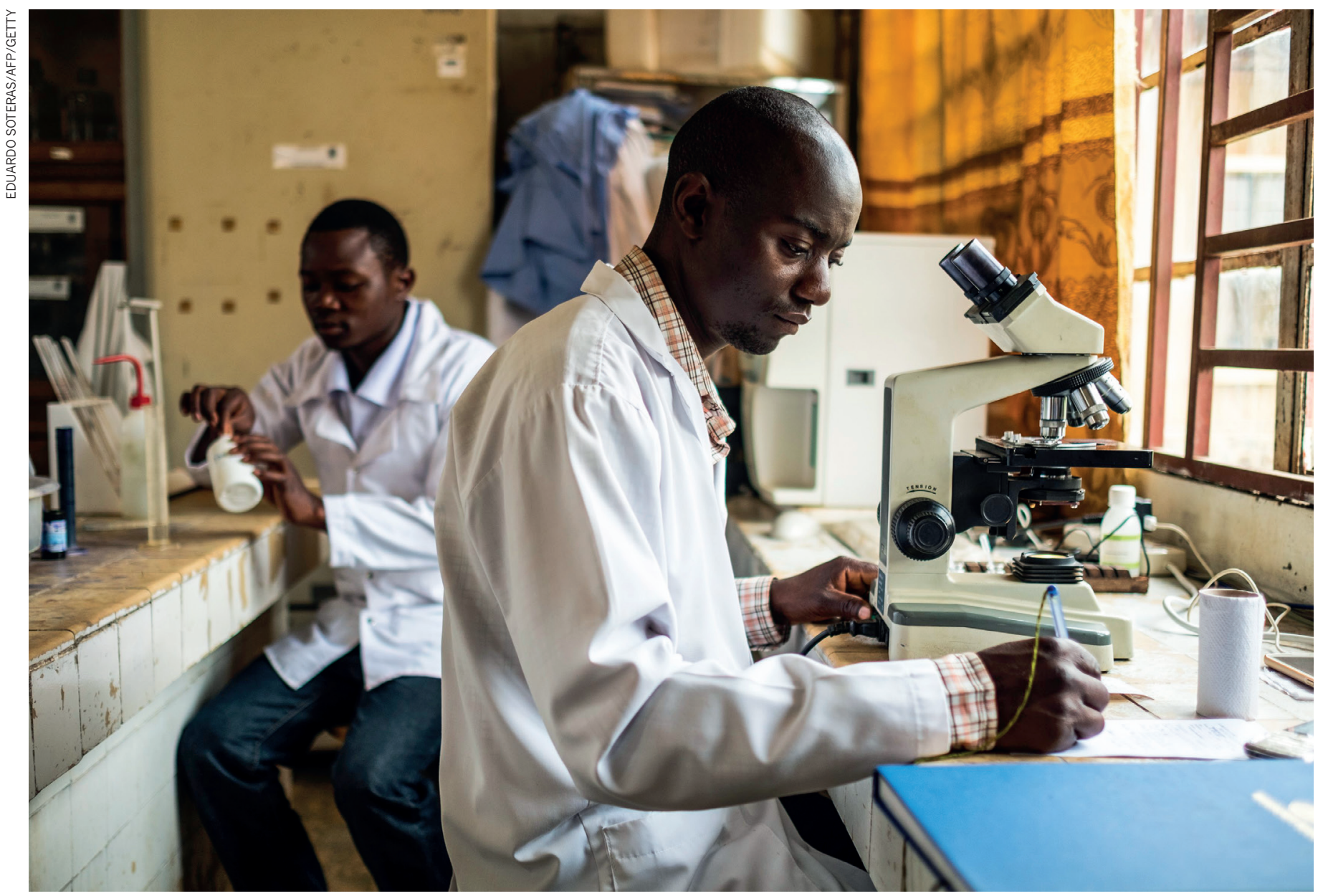

Students in a laboratory at the Catholic University of Graben in Butembo, Democratic Republic of the Congo.

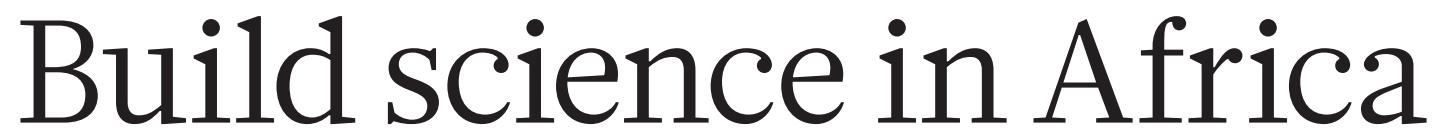

To cope with climate change and population growth, the continent urgently needs more home-grown researchers, argue Anagaw Atickem, Nils Chr. Stenseth and colleagues.

A frica's population is projected to nearly quadruple over the next century ${ }^{1}$. And that is following a staggering increase over just seven decades - from 200 million people in 1950 to 1.25 billion in 2018 (ref. 2). Meanwhile, temperatures across the continent are expected to rise by between $3{ }^{\circ} \mathrm{C}$ and $4{ }^{\circ} \mathrm{C}$ over the next century, bringing more drought, flooding, conflict and species loss ${ }^{3}$.

To face these formidable challenges,
Africa must improve its capabilities in higher education and research. Yet the quality of the scientific education provided at many universities on the continent has, if anything, deteriorated over the past two decades.

When two of us (A.A. and A.M.) moved from Addis Ababa University in Ethiopia to begin our PhDs in ecology and population genetics at the University of Oslo in Norway (in 2007 and 2012), we had never set foot in a genetics laboratory before, nor even seen a PCR machine. We had taken courses in statistics while pursuing master's degrees in Ethiopia, but had never touched a computer as part of our training. Thus, we had no practical experience in complex data analysis, and no idea about how to use software programs - such as the statistical packages R or ArcGIS - that are now common tools even in undergraduate courses in ecology, genetics and conservation 
biology in high-income countries.

Between us, we have experience in conducting research or mentoring researchers across sub-Saharan Africa (Botswana, Ethiopia, Kenya, Rwanda, Senegal, South Africa, Tanzania and Uganda) and in other parts of the world, including China, Canada, Germany, Norway, the United Kingdom and the United States. (Four of us were born in Africa, and trained there as well as in Europe and Canada; the rest of us are from highincome countries.) Drawing on this experience, we lay out the challenges of getting training in the biological and environmental sciences as an African student - at home and abroad.

In our view, the improvements so badly needed must happen mainly in Africa's higher-education system of public and private universities. But support from the international scientific community is essential. Global research and global stability stand to benefit.

\section{BOOM OR BUST?}

During the last quarter of the twentieth century, national governments and the World Bank prioritized primary education over higher education. From 1980 to 1996 , for instance, of the total budget for education in sub-Saharan Africa, $49 \%$ went to primary education and only $18 \%$ to higher education ${ }^{4}$.

In the early 2000s, governments and international agencies changed course, recognizing that the global economy of the twenty-first century would be driven by knowledge. A flurry of expansion in higher education across Africa followed ${ }^{5}$. In Ethiopia, for instance, between 2003 and 2012, the share of government expenditure on education was stable for primary education (at 35\%); for higher education, it increased from $28 \%$ to $43 \%$ (ref. 6).

The number of public and private universities has soared. Ethiopia, for example, now has 46; before 2000, it had 2. And between 2000 and 2013, total enrolment in higher education on the continent doubled to 12.2 million $^{7}$.

Yet most of Africa's universities lack wellequipped laboratories, libraries and other basic infrastructure, such as a reliable electricity supply or Internet connection. There is little funding for research (see 'Scant spending'). At Addis Ababa University, which ranks 37 th among the best African universities in the 2018 uniRank scale, each $\mathrm{PhD}$ student receives about US\$16,000 in total for 4 years of study. Even accounting for the differences in the cost of living, that's about $60 \%$ less than a typical PhD student receives in Europe or the United States. Faculty members are typically poorly paid and insufficiently trained. And many focus almost exclusively on lecturing because it is almost impossible to provide students

\section{TRENDS IN HIGHER EDUCATION}

Graduation from African universities is soaring but more students per teacher and decreased spending per student mean the quality of education is likely to fall.

\section{MORE GRADUATES}

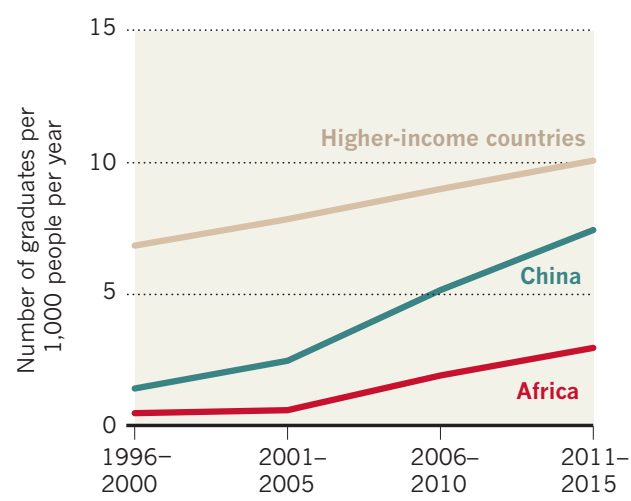

LESS SUPERVISOR CONTACT

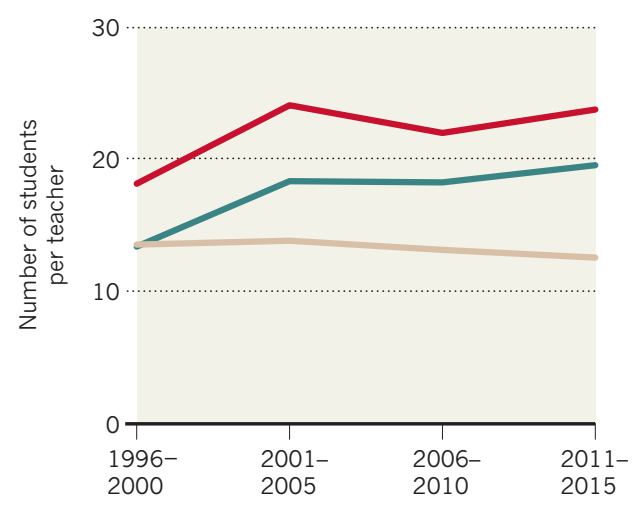

SPENDING PER STUDENT DECREASING

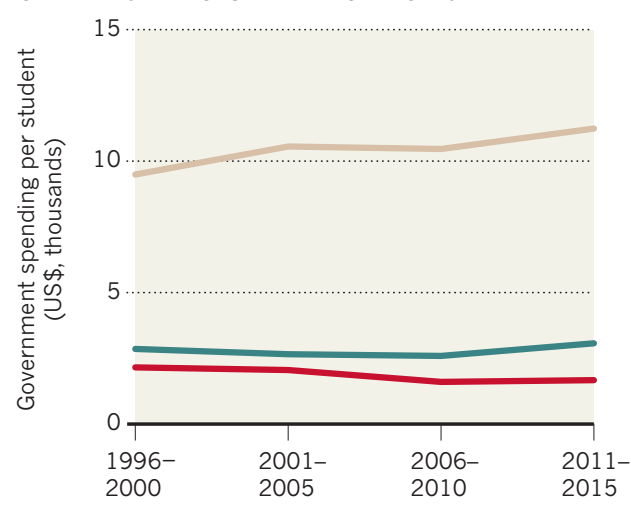

with hands-on research experience. What's more, students have little access to scientific publications other than those that are freely available online.

To make matters worse, most of the faculty members who advise graduate students have little teaching, research or advisory experience themselves. In Ethiopia in 2010 , less than $20 \%$ of university instructors held master's degrees, and less than $4 \%$ held $\mathrm{PhDs}^{8}$. Even in South Africa, the country with the highest total spending on research and development, only $39 \%$ of academic staff hold $\mathrm{PhDs}^{9}$.

This lack of training becomes a vicious circle. Graduate students from many universities produce theses that fall short of international standards, and rarely publish their work in high-impact journals.

As university enrolment in Africa continues to mushroom, its historically underfunded higher-education systems are being stretched to breaking point ${ }^{5}$. Across the continent, academics now teach more classes containing greater numbers of students than ever, leaving little time for research (see 'Trends in higher education'). Poorly paid faculty members often have second jobs (at other universities, in the private sector or with non-governmental agencies), which compounds the problems. In Nigeria, for example, it is not uncommon for an academic at one university to lecture at several others. Some courses are crammed into a couple of 12-hour days to enable lecturers to get to their next teaching post.

Despite these formidable obstacles, it is an exciting time for higher education and scientific research in Africa. Decades of investment in primary and secondary education have created more candidates for further education. And the growing number of people with Internet access is making collaborations much easier, both in Africa and with the rest of the world.

\section{OVERSEAS SUPPORT}

Currently, overseas support for African scientists comes mainly from national and multinational agencies such as the World Bank, from European countries such as France, Germany, Norway, Sweden and the United Kingdom, and from individual institutions and research mentors.

Since 2014, the World Bank has provided $\$ 500$ million to build or strengthen 46 African Higher Education Centers of Excellence for postgraduate education and applied research (see Nature 561, 16; 2018). So far, nearly half of these have attained international accreditation ${ }^{10}$ (see also go.nature.com $/ 2 \operatorname{kgcg} 9 \mathrm{x}$ ). In West and Central African countries alone, 8,000 master's and 2,000 PhD students have received training at these centres so far $^{10}$.

This and other 'donor-led' initiatives by the European Union and the United Nations are too fleeting. Funding often lasts for only five years or so, but needs to be provided over decades. Current trends to shrink long-term foreign aid are therefore worrying: in March, US President Donald Trump proposed a $23 \%$ cut in diplomatic and aid programmes of the type that would be needed to support intellectual growth in Africa ${ }^{11}$.

When it comes to nations supporting science in Africa, there is considerable variability in approach. Among high-income host countries, France had the most students from Africa in 2016 - around 95,000 (nearly $50 \%$ in master's courses and $8 \%$ 


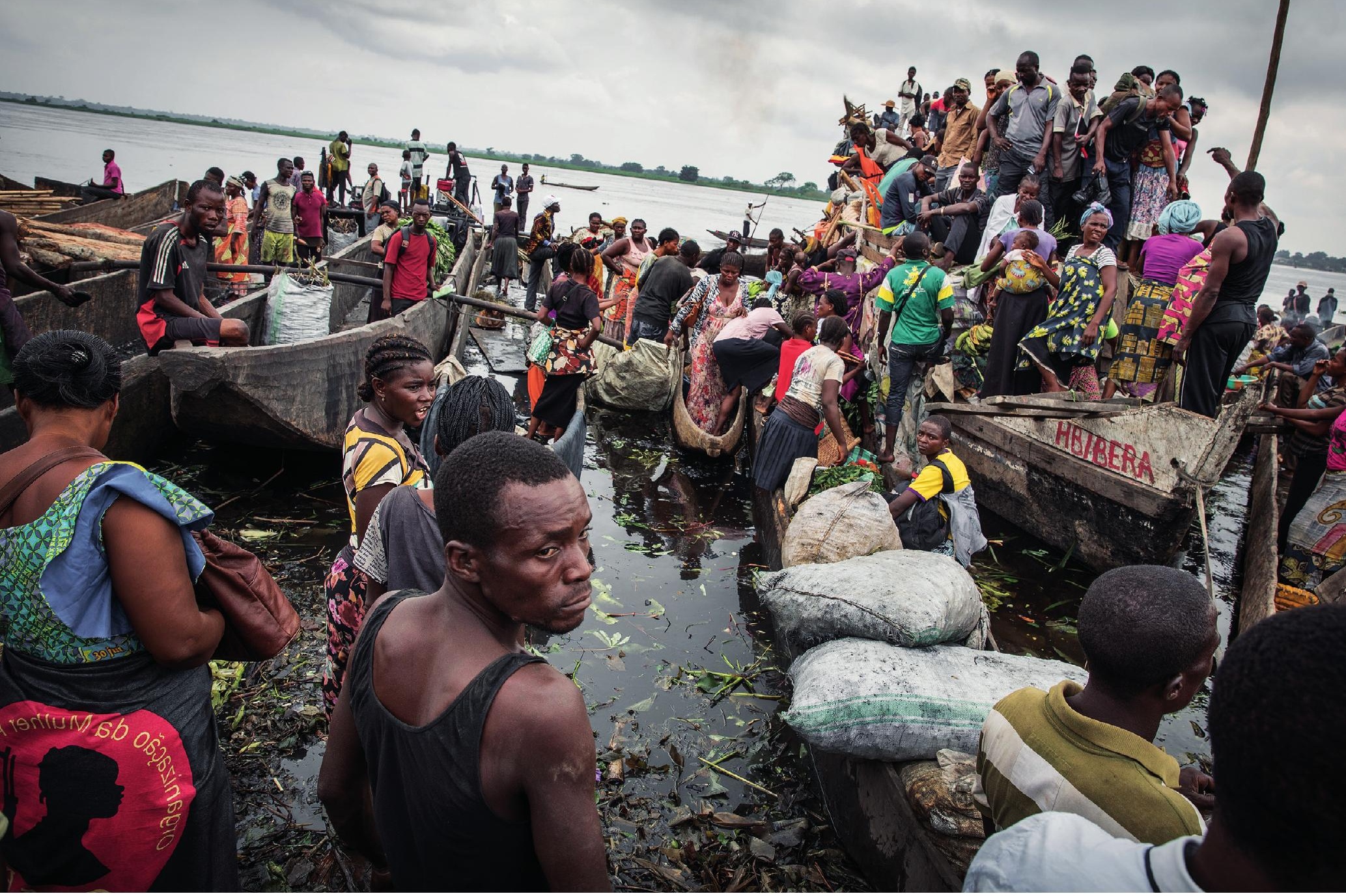

People sell food in Mbandaka, Democratic Republic of the Congo. Research into food security will help Africa face the challenge of feeding its growing populations.

in $\mathrm{PhD}$ programmes) ${ }^{12}$. And China is the fastest-growing destination for African students; according to Chinese ministry figures, it hosted around 62,000 in 2016, up from fewer than 2,000 in 2003 (see also Supplementary Information).

Since 1961, Sweden has provided longterm funding and mentoring to research groups at universities in low-income countries - mainly in Africa - in physics, chemistry and mathematics. Likewise, Norway has offered various scientific training programmes since 1970. Most notable is the Norwegian Partnership Programme for Global Academic Cooperation (NORPART), which from late 2017 replaced the Norwegian Quota Scholarship Scheme.

In 2018, NORPART awarded \$650,000 to three of us (N.C.S, A.B. and A.A.) to establish a mutually beneficial educational exchange programme between the University of Oslo and Addis Ababa University. This will promote the exchange of ideas between faculty members at each institution, and provide training to 26 Ethiopian and 15 Norwegian MSc students over the next 5 years.

Indeed, a crucial lesson from the Scandinavian experience is the importance of sustained investment over many decades for promoting self-sustaining, high-quality education and research in Africa.
Institutions in wealthier countries can also have important roles in growing scientific capacity in Africa. But too few regularly commit financial resources to this, or encourage their faculty members to get involved. And between-country connections generally rely on existing ties between individuals. These can be fragile and subject to the conditions of the granting agencies. University staff in Africa who have no contacts at a university in Norway cannot apply for NORPART funding, for example.

To be fair, mentoring students who are far from their home countries is demanding. As well as often lacking experience in

\section{SCANT SPENDING}

Africa devotes a tiny proportion of its GDP to research (data between 2009 and 2013).

North America and Western Europe

East Asia and the Pacific

\section{Sub-Saharan Africa}

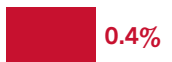

Regional categories are those used by the United Nations
Educational, Scientific and Cultural Organization. GDP, gross domestic product lab work, techniques in data analysis, writing research papers and so on, the students face cultural and language barriers. Most assistance programmes cover only an individual's costs, not those of dependants. But many African graduate students are older than most of their classmates from highincome countries and have families to support. Students can opt to leave their families at home, but this brings its own challenges.

\section{THREE STEPS TO CHANGE}

Incentivize faculty members in highincome countries. In our view, establishing more one-on-one mentorships for students with advisers from wealthier countries would most rapidly increase the rate at which science develops in Africa ${ }^{13}$.

Existing reward structures in academia favour individuals who win big grants and publish in the most prestigious journals. We think that such reward structures should adapt to meet the changing realities of a global society. Scientists who invest in international collaborations with African scientists and others from low-income countries could be given additional grants specifically for intensive mentoring, for instance. (Imagine how the rate of scientific development in Africa would change if every paper published by an African graduate student mentored by a researcher from 
a high-income country counted twice as much for tenure and promotion as a paper by a graduate student from the adviser's own university.)

Support MSc and $\mathrm{PhD}$ students. Institutions in high-income countries that support graduate students from Africa should offer modified programmes designed to meet their needs. These could include peermentoring programmes, and budgeting for students to do an extra year or more courses to enable degree completion.

Support scientists in Africa. Universities across Africa need to attract and retain more qualified educators by improving working conditions. This would support all academic researchers, but especially those early in their careers. It is relatively easy to obtain a faculty job in many African countries because of the increase in the number of universities ${ }^{14}$. But pay for academic scientists is typically abysmal ${ }^{15}$. (For instance, the gross monthly salary for a new $\mathrm{PhD}$ holder at Addis Ababa University is less than $\$ 500$, around the same as the monthly rent for a typical two-bedroom apartment nearby.) Also, the limited facilities and support for research in sub-Saharan Africa is dismaying for newly minted African $\mathrm{PhDs}^{13}$.

Many African PhD holders returning home after a stint abroad find it difficult - or impossible - to remain competitive in their field ${ }^{13}$, or to support a family on the salary provided. Instead, they opt for more lucrative work in the private sector or in international development. Others never return, contributing to Africa's 'brain drain $^{16,17}$.

To encourage African PhDs to stay in

\section{$2.6 \%$}

of the world's peer-reviewed scientific journal articles in 2013 included at least one author based in Africa.

science in Africa, foundations and other granting bodies worldwide should offer more multi-year research grants that support both basic and applied research on the continent. Funding schemes, similar to those in China and some European countries, should be developed to incentivize African students trained in high-income countries to contribute to scientific development in their country of origin (see Nature 569, 325-326; 2019).

\section{WHO BENEFITS?}

Developing science in Africa will improve global political and economic stability. And research as a whole will be strengthened - by different ideas born of different challenges and experiences - if many more African scientists become key members of the global scientific community.

Ultimately, it must be Africans themselves who drive the transition towards a stronger Africa. Wealthy African entrepreneurs could help with this. Governments across the continent must bring their own money to higher education and research. But improving Africa's higher-education and research capacity will also require considerable spending by - and structural change in - the academic and financial institutions of richer nations. Most

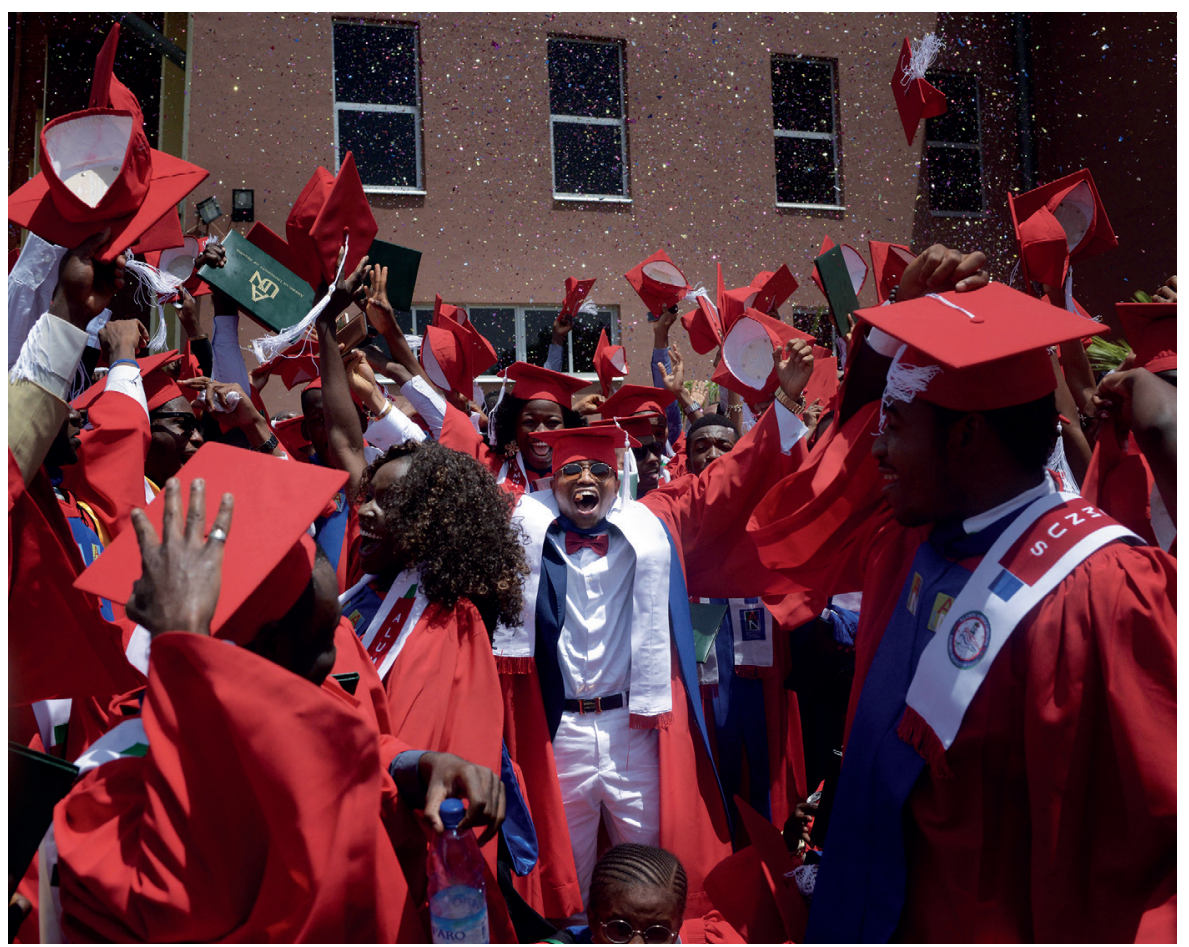

The class of $\mathbf{2 0 1 5}$ graduating from the American University of Nigeria in Yola

importantly, scientists working in highincome countries or emerging economies need to change the way they view, value and reward collaborations involving researchers from Africa. It is only by working together that sustainable top-level African universities will develop - institutions that are needed if we are to tackle the major global issues of our time.

Anagaw Atickem is an adjunct assistant professor in the Department of Zoological Sciences at Addis Ababa University, Ethiopia, and is associated with the Centre for Ecological and Evolutionary Synthesis, University of Oslo, Norway. Nils Chr.

Stenseth is professor at the Faculty of Mathematics and Natural Sciences and at the Centre for Ecological and Evolutionary Synthesis at the University of Oslo, Norway; honorary professor in the Department of Zoological Sciences, Addis Ababa University, Ethiopia; and an elected member of the World Academy of Sciences. Peter J.

Fashing, Nga Nguyen, Colin A. Chapman, Afework Bekele, Addisu Mekonnen, Patrick A. Omeja, Urs Kalbitzer. e-mail:n.c.stenseth@ibv.uio.no

1. United Nations Department of Economic and Social Affairs. World Population Prospects: The 2015 Revision. Key Findings and Advance Tables (UN, 2015).

2. Altenburg, T. et al. Foresight Africa: Top Priorities for the Continent in 2019 (Brookings Inst., 2019).

3. Malhi, Y., Adu-Bredu, S., Asare, R. A., Lewis, S. L. \& Mayaux, P. Phil. Trans. R. Soc. B 368, 20120312 (2013)

4. Stasavage, D. Am. J. Polit. Sci. 49, 343-358 (2005).

5. World Bank. Accelerating Catch-up: Tertiary Education for Growth in Sub-Saharan Africa (World Bank, 2009).

6. World Bank. Ethiopia Public Expenditure Review 2015 (World Bank, 2016)

7. UN Educational, Scientific and Cultural Organization. UNESCO Institute for Statistics: Higher Education (2018).

8. Reisberg, L. \& Rumbley, L. E. Int. Higher Edu. 45 , 23-24 (2010).

9. Cloete, N., Sheppard, C. \& Bailey, T. in Knowledge Production and Contradictory Functions in African Higher Education (eds Cloete, N., Maasen, P. \& Bailey, T.) 75-108 (African Minds, 2015).

10.World Bank. African Centers Of Excellence Project (P126974) (World Bank, 2018).

11.Rabinowitz, K. \& Uhrmacher, K. 'What Trump proposed in his 2020 budget' The Washington Post (11 March 2019).

12. Marshall, J. 'International African students in France - A Profile' University World News (17 November 2016)

13. Dike, V. N. et al. Nature Clim. Change 8, 447-449 (2018).

14. Teferra, D. J. High. Edu. Africa 11, 19-51 (2013).

15.UN Educational, Scientific and Cultural Organization. UNESCO Science Report 2010: The Current Status of Science Around the World (UNESCO, 2010).

16. Watkins, A. \& Mandell, J. Global Forum Action Plan: Science, Technology and Innovation Capacity Building Partnerships for Sustainable Development 32 (World Bank, 2010).

17.Capuano, S. \& Marfouk, A. J. Comp. Policy Anal. Res. Practice 15, 297-314 (2013) article: see go.nature.com/31sxhsx 